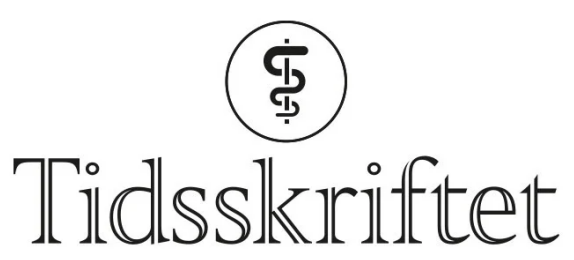

DEN NORSKE LEGEFORENING

\title{
En kvinne i 50-årene med langvarig muskelsvakhet
}

NOE Å LARE AV

\section{CECILIE F. RUSTAD}

Seksjon for klinisk genetikk

Avdeling for medisinsk genetikk

Oslo universitetssykehus, Rikshospitalet

Cecilie F. Rustad er spesialist i medisinsk genetikk og overlege.

Forfatteren har fylt ut ICMJE-skjemaet og oppgir ingen interessekonflikter.

\section{KRISTIAN TVETEN}

Seksjon for medisinsk genetikk

Sykehuset Telemark

Kristian Tveten er ph.d., klinisk laboratoriegenetiker og overingeniør.

Forfatteren har fylt ut ICMJE-skjemaet og oppgir ingen interessekonflikter.

\section{GEIR J. BRAATHEN}

Seksjon for medisinsk genetikk

Sykehuset Telemark

Geir J. Braathen er ph.d., master i helseadministrasjon, spesialist i nevrologi og medisinsk genetikk og seksjonsoverlege.

Forfatteren har fylt ut ICMJE-skjemaet og oppgir ingen interessekonflikter.

\section{ELSE MERCKOLL}

Avdeling for radiologi

Oslo universitetssykehus, Rikshospitalet

Else Merckoll er spesialist i radiologi og overlege.

Forfatteren har fylt ut ICMJE-skjemaet og oppgir ingen interessekonflikter.

\section{EVA KIRKHUS}

Avdeling for radiologi

Oslo universitetssykehus, Rikshospitalet

Eva Kirkhus er ph.d., spesialist i radiologi og overlege.

Forfatteren har fylt ut ICMJE-skjemaet og oppgir ingen interessekonflikter.

\section{HANNE LUDT FOSSMO}

Seksjon for sjeldne nevromuskulære tilstander

Nevrologisk avdeling

Oslo universitetssykehus, Rikshospitalet

og

Vikersund Bad Rehabiliteringssenter 
Hanne Ludt Fossmo er spesialfysioterapeut samt FoU-leder og koordinator for FoU-nettverket for tverrfaglige spesialiserte rehabiliteringsinstitusjoner.

Forfatteren har fylt ut ICMJE-skjemaet og oppgir ingen interessekonflikter.

\section{KRISTIN ØRSTAVIK}

krorstav@ous-hf.no

Seksjon for sjeldne nevromuskulære tilstander

Nevrologisk avdeling

Oslo universitetssykehus, Rikshospitalet

Kristin Ørstavik er dr.med., spesialist i nevrologi og klinisk nevrofysiologi, overlege og seksjonsleder. Forfatteren har fylt ut ICMJE-skjemaet og oppgir ingen interessekonflikter.

\section{En kvinne ble henvist til utredning fordi hun ønsket å vite årsaken til diagnosen hun hadde fått som tenåring, og videre prognose. Utvidet gentesting og grundig gjennomgang av sykehistorien viste at den opprinnelige diagnosen var feil. Kasuistikken illustrerer at økte muligheter for gentesting kan ha konsekvenser for oppfølging og behandling.}

En kvinne i 50 -årene ble født med en feilstilling i føttene som skal ha normalisert seg spontant $i$ løpet av noen uker etter fødselen. Hun gikk på tcerne fra ettårs alder, og en av hennes foreldre var også tågjenger. Frem til skolealder kunne hun løpe og gå i trapper, men over noen år mistet hun gradvis evnen til å løpe. Som tenåring fikk hun diagnosen arthrogryposis multiplex congenita av nevrolog, og hun og hennes affiserte forelder var til genetisk veiledning, hvor det ble konkludert med artrogrypose av den distale og dominant arvelige typen. Diagnosen ble stilt på bakgrunn av medfødt oppslåtte føtter og nedsatt bevegelighet $i$ ankler, albuer og fingre samt familiehistorikk.

Arthrogryposis multiplex congenita (AMC) er en betegnelse som brukes for å beskrive en gruppe medfødte tilstander kjennetegnet av leddkontrakturer i to eller flere kroppsregioner (1). Arthrogryposis multiplex congenita er en klinisk betegnelse, og ikke en årsaksdiagnose. Tilstanden kan ha ulike årsaker, inkludert genetiske. Også forhold i svangerskapet, som for eksempel føtal hypo- eller akinesi, kan føre til tilstanden (1 $)$. Bevegeligheten er nedsatt i de affiserte leddene med eller uten muskelsvakhet. Kontrakturene progredierer ikke til tidligere uaffiserte ledd, men kan endre seg over tid med vekst og fysikalsk behandling. Ryggsøylen kan være affisert. Noen former involverer flere organsystemer. Basert på internasjonale tall er det antatt at det fødes 15-20 barn med forandringer forenlig med arthrogryposis multiplex congenita i Norge per år $(\underline{2-4}$.). Det er vanlig å dele tilstanden inn i tre undergrupper: amyoplasi, distale artrogryposer og syndromer hvor arthrogryposis multiplex congenita inngår (5). Amyoplasi kjennetegnes av symmetriske, lite tøyelige kontrakturer og typiske feilstillinger i overekstremitetene og har antatt ikke-genetisk årsak. Distale artrogryposer og syndromer hvor arthrogryposis multiplex congenita inngår, har oftest genetisk årsak. Det er stor variasjon i hvordan tilstanden kommer til uttrykk, avhengig av årsaken (므).

Det kliniske bildet frem til 3o-års alder var preget av redusert leddbevegelighet distalt, $i$ hender, ankler og den ene albuen, men hun kjente seg sterk og sprek. Fra 3o-års alder hadde hun et stillesittende yrke. Etter en fødsel $i$ 3o-årene ble hun svakere og mindre fysisk utholdende. Hun fikk vansker med å gå i trapper og motbakker og klarte ikke å reise seg fra gulvet uten støtte. Da hun vari midten av 4o-årene, ble det på grunn av den økende svakheten gjort MR-undersøkelse av lumbosakralcolumna og bekkenet, som viste markert fettinfiltrasjon i en rekke proksimale muskler. Med økende plager og alder ønsket pasienten mer kunnskap om tilstanden. Hun var opptatt av hva hun kunne forvente i fremtiden, og kontaktet derfor et kompetansesenter. Der ble hun henvist til genetisk utredning. 
Til å begynne med fikk hun genetisk konsultasjon per telefon. Det ble rekvirert en sekvenseringsundersøkelse (.7), som omfattet de genene som oftest er forbundet med distal artrogrypose. Resultatet var normalt. Kvinnen møtte så til konsultasjon hos genetiker. Hun fortalte at hun frem til begynnelsen av 3o-årene hadde kunnet reise seg fra knestående stilling, og at hun deretter opplevde gradvis redusert kraft i lårene. Det var gjentatte ganger påvist lett forhøyet konsentrasjon av kreatinkinase (CK) i serum. Ved klinisk undersøkelse hadde pasienten redusert kraft i lårene og ekstensjonsevne i albuene, og hun kunne ikke ekstendere håndledd og fingre samtidig. Hun hadde flere keloide arr i huden.

Den affiserte forelderen hadde også hatt bøyde albuer, stivhet i fingrene og økende svai i korsryggen. Forelderen utviklet etter hvert sviktende kncer, gikk på tcerne, ble gradvis redusert fysisk og døde i 70 årene.

Etter samtykke fra kvinnen ble hennes tidligere journal innhentet, og etter samtykke fra kvinnen og hennes gjenlevende forelder ble også journalen til den avdøde forelderen innhentet. Ved gjennomgang av den affiserte forelderens journal viste det seg at det hadde vart mistanke om myopati i forbindelse med en annen sykdom i 7o-årsalderen. Dette kjente ikke kvinnen til. Hennes egen journal avdekket at hun som tenåring var blitt vurdert hos ortoped, og at diagnosen CharcotMarie-Tooths sykdom var blitt nevnt.

Den reduserte kraften i lårene, fettinfiltrasjonen påvist på MR og den lett forhøyede CKverdien samt de keloide arrene svekket mistanken om arthrogryposis multiplex congenita, da det ikke er beskrevet økt tendens til keloid og heller ikke forhøyet CK ved denne tilstanden. I lys av dette kunne man latt være å gjennomføre genpaneltesting for distal artrogrypose. Men gitt stor klinisk og genetisk heterogenitet ved arthrogryposis multiplex congenita vurderes allikevel analysen å ha vært aktuell ut fra de opplysninger som forelå da den ble rekvirert. Sekvenseringsundersøkelsen var eksombasert, dvs. at genvariantdata fra samtlige gener forelå, men at kun genene omfattet av genpanelet for arthrogryposis multiplex congenita ble undersøkt. I neste omgang var det mulig å utvide analysen bioinformatisk til (undersøkelse av) andre relevante gener.

Redusert kraft proksimalt, fettinfiltrasjon på MR og lett forhøyet CK ga klinisk mistanke om Bethlemmyopati, og gener assosiert med dette ble undersøkt.

Undersøkelsen påviste en heterozygot og sannsynlig sykdomsgivende sekvensvariant NM_o01849.3:c.854_855del p.(Gln285Argfs $\left.{ }^{*} 26\right)$ i COL6A2-genet (kollagen 6A2). Den samme varianten ble påvist ved målrettet undersøkelse av blodprøve fra affisert forelder som var lagret etter tidligere genetisk konsultasjon. Varianten ble ved laboratoriet vurdert som sannsynlig sykdomsgivende (ramme 1) (ㅁ․9.), og kvinnen fikk således diagnosen sannsynlig Bethlem-myopati basert på sykehistorie, kliniske undersøkelser, familieanamnese og funn ved genetisk testing.

\section{Ramme 1 Vurdering av sekvensvarianten.}

Sekvensvarianter som påvises ved genetiske analyser, vurderes etter konsensusretningslinjer for varianttolkning, for eksempel ACMG-(American College of Medical Genetics and Genomics), AMP-(Association for Molecular Pathology) og ABC-systemet (므, 9.), som benigne, sannsynlig benigne, uklassifiserbare (varianter av usikker signfikans, såkalte VUS), sannsynlig sykdomsgivende eller sikkert sykdomsgivende. Av betydning for tolkning av en variant er gradering av variantens molekylærbiologiske konsekvens i lys av den kliniske fenotypen.

Varianten som ble påvist hos kvinnen i denne kasuistikken, resulterer i delesjon av de siste to baseparene i ekson 6 i det ene av hennes to kopier av COL6A2-genet. Dette kan medføre enten avvikende spleising eller innføring av et leserammeskift med et prematurt stoppkodon nedstrøms. Det første vil føre til forkorting av kollagen-trippelheliksrepetisjonen. Det siste vil føre til degradering av COL6A2-mRNA via nonsens-mediert degradering (NMD). Varianten var ikke tidligere rapportert som sykdomsgivende og hadde ingen frekvens i normalvariasjonsdatabasen gnomAD (Genome Aggregation Database). Liknende varianter er beskrevet som årsak til type 6-kollagenopati. 
Kollagen 6 danner et nettverk i ekstracellulær matriks i muskler, hud, sener og annet vev. De tre kollagen 6-genene COL6A1, COL6A2 og COL6A3 koder for hver sin alfakjede, som til sammen danner kollagen 6-proteinet. Sykdomsgivende sekvensvarianter i COL6A1, COL6A2 og COL6A3 er årsak til et klinisk kontinuum av muskelsykdom fra Bethlem-myopati i den

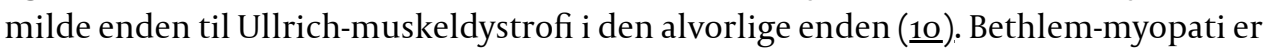
kjennetegnet av kombinasjonen av proksimal muskelsvakhet og varierende grad av kontrakturer som affiserer de lange fingerfleksorene, albuer og ankler. Ved Bethlemmyopati er det også beskrevet hudforandringer, som for eksempel keloider, og normal eller lett forhøyet CK-verdi. Arvegangen ved Bethlem-myopati er autosomal dominant. Når mor eller far har tilstanden, er det $50 \%$ sannsynlighet for at den sykdomsgivende sekvensvarianten nedarves i hvert svangerskap. Det kan være variasjon i hvordan en sykdomsgivende variant i COL6A1-genet kommer til uttrykk klinisk, selv innenfor samme familie (1ㅡ). En forelder kan for eksempel være mindre affisert enn sitt barn eller omvendt.

Kvinnen ble henvist videre for nevrologisk vurdering og treningsråd. Klinisk nevrologisk undersøkelse beskrev som tidligere keloid, selv etter myggestikk, og de tidligere konstaterte fleksjonskontrakturene i fingre og albuer. Det ble også beskrevet kontrakturer i akillessenene som gjorde at hun ikke kunne gå på hcelene. Hun hadde svakhet proksimalt i over-og underekstremiteter samt svakhet $i$ trunkusmuskler ettersom hun måtte bruke armene for å sette seg opp fra liggende stilling. Hofteleddene var hypermobile. Disse funnene var i tråd med diagnosen Bethlem-myopati. På bakgrunn av klinisk undersøkelse forenlig med myopati, positiv gentest og tidligere påvist fettinfiltrasjon på MR fant man ikke indikasjon for elektromyografi. Sykdomsbildet ble etter samtykke fra kvinnen diskutert anonymt $i$ en nasjonal videokonferanse med kolleger fra hele landet som arbeider med sjeldne muskelsykdommer. Det ble anbefalt å gjøre MR-undersøkelse av alle muskler, og disse viste et karakteristisk mønster med fettinfiltrasjon hovedsakelig i proksimale muskler i over- og underekstremiteter (figur 1).

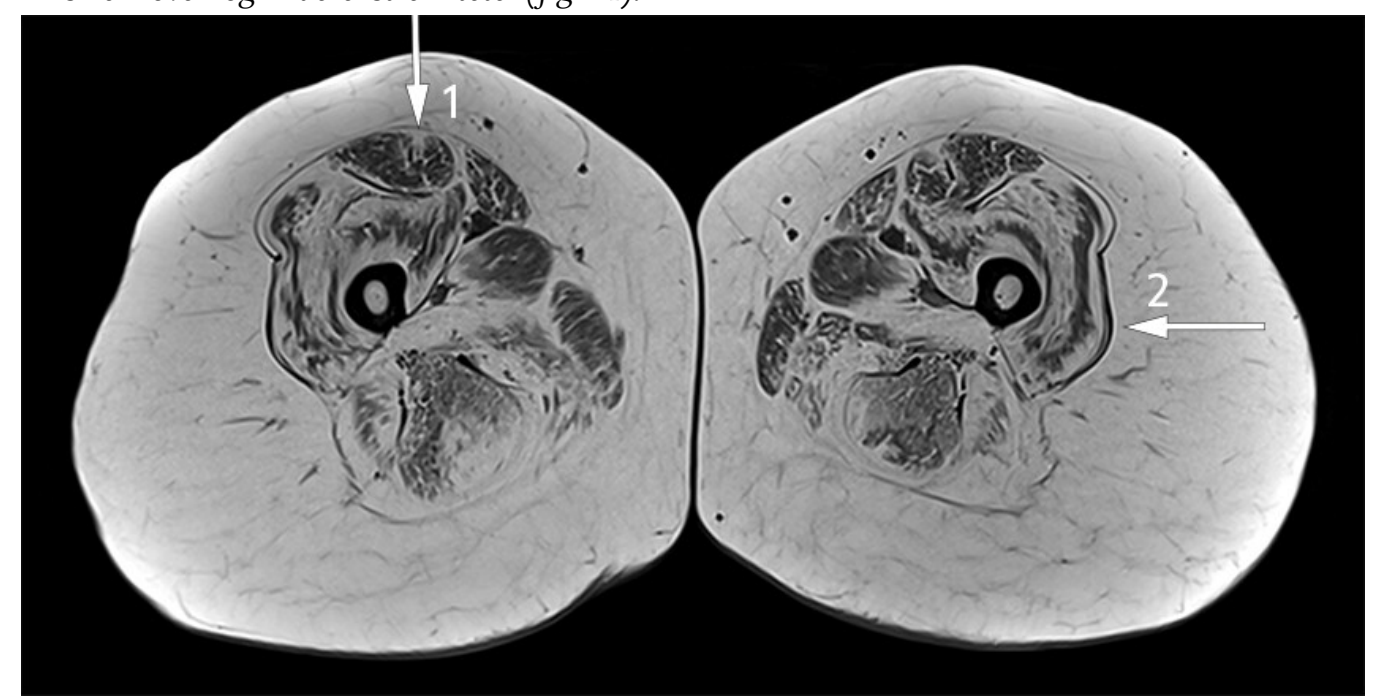

Figur 1 Transversalt T1-vektet MR-bilde av lårene viser symmetrisk patologisk

fettinfiltrasjon i muskulaturen med «target sign» i musculus rectus femoris (pil 1) som representerer sentral fettinfiltrasjon med bedre bevart muskulatur perifert, og "sandwich sign» i musculus vastus lateralis som representerer perifer fettinfiltrasjon med bedre bevart muskulatur sentralt (pil 2) (12-14).

Ved Bethlem-myopati ses typisk moderat svekkelse og atrofi av musklene i trunkus og ekstremitetene. Det er gjerne mest uttalt proksimalt og i ekstensorer. Langsom progresjon er vanlig, og over to tredjedeler av pasientene over 50 år trenger mobilitetsst $\varnothing t t e$, for

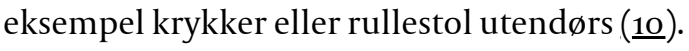

MR-undersøkelse benyttes i økende grad i utredning av sykdommer som affiserer muskulatur, først og fremst for å velge egnet biopsisted, men også som diagnostisk verktøy for å gjenkjenne utbredelse og mønstre av muskelødem og fettinfiltrasjon. Kollagen 6- 
relaterte myopatier som Bethlem-myopati har et distinkt, men ikke patognomonisk mønster med sentral fettinfiltrasjon i m. rectus femoris og perifer fettinfiltrasjon i m. vastus lateralis med relativ utsparing sentralt, som resulterer i «sandwich-tegnet» (12-14).

Pasienten var fornøyd med å få en spesifikk genetisk diagnose og informasjon om hva som kan forventes i fremtiden ved denne tilstanden. I tillegg fikk hun råd om moderat trening slik det er anbefalt for pasienter med arvelige muskelsykdommer(15-17.).

\section{Diskusjon}

Arthrogryposis multiplex congenita er beskrevet å være en del av flere enn 400 forskjellige tilstander. Alvorlighetsgrad, ekstraartikulære manifestasjoner, prognose, arvegang, oppfølging og behandling varierer avhengig av årsak. Hos denne pasienten førte den genetiske utredningen til at diagnosen ble revidert fra arthrogryposis multiplex congenita til autosomal dominant Bethlem-myopati. Endret diagnose er ikke så uvanlig ved enkelte arvelige tilstander hvor diagnosen er stilt før gentesting ble bredt tilgjengelig (표). Slik kompetansesentrene i Norge er organisert, kan endring av diagnose medføre endret kompetansesentertilhørighet, slik det gjorde i dette tilfellet.

En presis diagnose med genetisk årsak gjør det mulig å gi informasjon om hva som er beskrevet om den aktuelle diagnosen for forskjellige aldersgrupper. Det var dette kvinnen $\emptyset$ nsket da hun ble henvist til genetisk konsultasjon. Diagnosespesifikk informasjon var tilgjengelig, og hun kunne henvises til aktuelle spesialister. Tidlig i utredningsforløpet ble det rekvirert eksombasert genpaneltesting. Dette gjorde det mulig å få ytterligere gener vurdert gjennom utvidet bioinformatisk analyse, og bidro til kortere svartid samt til at ny genetisk analyse ikke medførte økt kostnad.

Mange voksne som lever med AMC-diagnosen er ikke gentestet, da testmulighetene var begrenset tidligere. Mulighetene for gentesting er i Norge nå svært gode, og mange kan dermed få en mer spesifikk diagnose. Dette er viktig i flere sammenhenger. For foreldrene til et lite barn med arthrogryposis multiplex congenita kan det for eksempel være avgjørende for å få avklart om det skal startes noen bestemt form for behandling for barnet, og om diagnosetilpasset oppfølging kan igangsettes. En avklart genetisk diagnose vil kunne gi informasjon om hva som er beskrevet om tilstanden tidligere.

MR ble benyttet som et supplement for å understøtte kvinnens nye diagnose. Ved utredning av arvelige muskelsykdommer kan også muskelbiopsi hjelpe i arbeidet med å stille en diagnose, men med bedret genetisk diagnostikk brukes dette i mindre grad. Ved Bethlem-myopati kan uspesifikke myopatiske forandringer ses ved biopsi, mens eventuell farging på kollagen 6 kan avdekke mer spesifikk diagnose (19).

Hos denne pasienten ga det kliniske bildet og sykehistorien mistanke om en annen diagnose enn den hun fikk som barn. Ettersom arthrogryposis multiplex congenita omfatter så mange forskjellige diagnosegrupper, er det i lys av den utviklingen som har vært innen genetisk testing, hensiktsmessig å tilby genetisk utredning ved denne tilstanden. Sekvenseringsundersøkelse av et utvalg av gener gir mulighet for mer presis diagnose og er lett tilgjengelig i Norge. En presis diagnose kan ha konsekvenser for behandlingsvalg og planlegging av svangerskap, og kan i noen tilfeller være av betydning for slektninger.

Pasienten og gjenlevende forelder har gitt samtykke til at artikkelen blir publisert. Artikkelen er fagfellevurdert.

1. Dahan-Oliel N, Cachecho S, Barnes D et al. International multidisciplinary collaboration toward an annotated definition of arthrogryposis multiplex congenita. Am J Med Genet C Semin Med Genet 
2. Bamshad M, Van Heest AE, Pleasure D. Arthrogryposis: a review and update. J Bone Joint Surg Am 2009; 91 (Suppl 4): 40-6. [PubMed][CrossRef]

3. Linnet KM, Balslev T, Møller-Madsen B. Arthrogryposis multiplex congenita. Ugeskr Læger 2015; 177: V12140712. [PubMed]

4. Hall JG, Kimber E, van Bosse HJP. Genetics and Classifications. J Pediatr Orthop 2017; 37 (Suppl 1): S4-8. [PubMed][CrossRef]

5. Nouraei H, Sawatzky B, MacGillivray M et al. Long-term functional and mobility outcomes for individuals with arthrogryposis multiplex congenita. Am J Med Genet A 2017; 173:1270-8. [PubMed] [CrossRef]

6. Dai S, Dieterich K, Jaeger M et al. Disability in adults with arthrogryposis is severe, partly invisible, and varies by genotype. Neurology 2018; 90: e1596-604. [PubMed][CrossRef]

7. Sørensen IW, Prescott T, F Rustad C et al. Genpaneltesting. Tidsskr Nor Legeforen 2020; 140. doi: 10.4045/tidsskr.19.0535. [PubMed][CrossRef]

8. Richards S, Aziz N, Bale S et al. Standards and guidelines for the interpretation of sequence variants: a joint consensus recommendation of the American College of Medical Genetics and Genomics and the Association for Molecular Pathology. Genet Med 2015; 17: 405-24. [PubMed] [CrossRef]

9. Houge G, Laner A, Cirak S et al. Stepwise ABC system for classification of any type of genetic variant. Eur J Hum Genet 2021; 29. doi: 10.1038/s41431-021-00903-z. [PubMed][CrossRef]

10. Foley AR, Mohassel P, Donkervoort S et al. Collagen VIRelated Dystrophies. I: Adam MP, Ardinger HH, Pagon RA et al., red. GeneReviews®. Seattle, WA: University of Washington, 1993-2021. https://www.ncbi.nlm.nih.gov/books/NBK1503/ Lest 14.9.2021.

11. Peat RA, Baker NL, Jones KJ et al. Variable penetrance of COL6A1 null mutations: implications for prenatal diagnosis and genetic counselling in Ullrich congenital muscular dystrophy families. Neuromuscul Disord 2007; 17: 547-57. [PubMed][CrossRef]

12. Mercuri E, Lampe A, Allsop J et al. Muscle MRI in Ullrich congenital muscular dystrophy and Bethlem myopathy. Neuromuscul Disord 2005; 15:303-10. [PubMed][CrossRef]

13. Salim R, Dahlqvist JR, Khawajazada T et al. Characteristic muscle signatures assessed by quantitative MRI in patients with Bethlem myopathy. J Neurol 2020; 267: 2432-42. [PubMed][CrossRef]

14. Fu J, Zheng YM, Jin SQ et al. Target and sandwich signs in the thigh muscles have high diagnostic values for collagen VI-realted myopathies. Chin Med J (Engl) 2016; 129: 1811-6. [PubMed][CrossRef]

15. Fossmo HL, Holtebekk E, Giltvedt K et al. Fysisk trening hos voksne med arvelig muskelsykdom. Tidsskr Nor Legeforen 2018; 138. doi:10.4045/tidsskr.17.1024. [PubMed][CrossRef]

16. Vissing CR, Hedermann G, Vissing J. Moderate-intensity aerobic exercise improves physical fitness in bethlem myopathy. Muscle Nerve 2019; 60: 183-8. [PubMed][CrossRef]

17. Treningsråd til voksne med muskelsykdom. Oslo/Siggerud: Frambu kompetansesenter for sjeldne diagnoser, Enhet for medfødte og arvelige nevromuskulære tilstander og Nevromuskulært kompetansesenter, 2019. https://unn.no/Documents/Kompetansetjenester,\%20sentre\%20og\%2ofagr\%C3\%A5d/Nevromuskul\%C3\%A6rt\%2okompetansesenter\%2o(NMK)/Trenings\%C3\% A5d\%2otil\%2ovoksne\%2omed\%2omuskelsykdom\%2oII.pdf Lest 14.9.2021.

18. Stray-Pedersen A, Sorte HS, Samarakoon P et al. Primary immunodeficiency diseases: Genomic approaches delineate heterogeneous Mendelian disorders. J Allergy Clin Immunol 2017; 139: 232-45. [PubMed][CrossRef]

19. Bushby KM, Collins J, Hicks D. Collagen type VI myopathies. Adv Exp Med Biol 2014; 802: 185-99. [PubMed][CrossRef]

Publisert: 7. januar 2022. Tidsskr Nor Legeforen. DOI: 10.4045/tidsskr.21.0038

Mottatt 13.1.2021, første revisjon innsendt 23.8.2021, godkjent 14.9.2021.

Publisert under åpen tilgang CC BY-ND. Lastet ned fra tidsskriftet.no 26. april 2023. 